\title{
Dietary macro- and micro-nutrients intake adequacy at 6th and 12th month post- bariatric surgery
}

Maryam Ziadlou', Firoozeh Hosseini-Esfahani ${ }^{2}$, Hassan Mozaffari Khosravi ${ }^{3}$, Farhad Hosseinpanah ${ }^{4}$, Maryam Barzin ${ }^{4}$, Alireza Khalaj ${ }^{5}$ and Majid Valizadeh ${ }^{4^{*}}$ (D)

\begin{abstract}
Background: Bariatric surgery (BS) is considered as an effective solution to control morbid obesity. Food restrictions resulting from the operation may decrease dietary nutrient intakes, particularly during the first year after BS. This study mainly aimed to assess the adequacy of dietary nutrient intakes at 6th and 12th month after BS.

Method: Of the severely obese participants in the Tehran obesity treatment study in 2015-2016, 58 patients undergoing Roux-En-Y gastric bypass $(N=16)$ or sleeve gastrectomy $(N=42)$ were selected from Tehran Obesity Treatment Center. To assess the patients' dietary intake, a three-day, 24-h dietary recall was obtained on three unscheduled days (two non-consecutive weekdays and one weekend day) at 6th and 12th month after BS. To evaluate the adequacy of nutrient intake, the patients' intakes were compared to the current dietary reference intakes (DRIs), including estimated average requirements (EAR) or Adequate Intakes (AI).
\end{abstract}

Results: The mean age of the participants (71\% women) undergoing BS was $37 \pm 8$ years. Anthropometric parameters significantly decreased at the 12th month after BS. The percentage of energy from carbohydrate intake increased significantly between the 6th and 12th month after BS $(P=0.04)$. The mean \pm SD of protein intake was lower than the recommended dosage with a dramatic decrease from $45 \pm 30$ to $31 \pm 15$ ( $\mathrm{g} /$ day) between the two intervals $(P=0.001)$. The mean intake of saturated fatty acid (SFA) decreased dramatically $(P<0.001)$ from 6 to 12 month; however, the median intake of n3-polyunsaturated fatty acid (n3-PUFA) intake increased $(P=0.02)$. None of the participants showed nutrient intake adequacy in terms of biotin, fat soluble vitamins, pantothenic acid, potassium, and zinc. Moreover, less than $10 \%$ of the participants showed nutrient intake adequacy in terms of folate, magnesium, manganese, and calcium according to DRls during the both intervals after BS.

Conclusion: Bariatric surgery can reduce dietary intakes, which is more obvious 12 months after the surgery. Out of 21 micronutrients, nearly all could not met the EAR and were received $<50 \%$, also had significant reduction from the 6th to12th month after surgery.

Keywords: Bariatric surgery, Sleeve gastrectomy, Roux-en-Y gastric bypass, Nutrient intake adequacy

\footnotetext{
* Correspondence: mvalizadeh47@yahoo.com

${ }^{4}$ Obesity Research Center, Research Institute for Endocrine Science, Shahid Beheshti University of Medical Sciences, Tehran, IR, Iran

Full list of author information is available at the end of the article
}

(C) The Author(s). 2020 Open Access This article is licensed under a Creative Commons Attribution 4.0 International License, which permits use, sharing, adaptation, distribution and reproduction in any medium or format, as long as you give appropriate credit to the original author(s) and the source, provide a link to the Creative Commons licence, and indicate if changes were made. The images or other third party material in this article are included in the article's Creative Commons licence, unless indicated otherwise in a credit line to the material. If material is not included in the article's Creative Commons licence and your intended use is not permitted by statutory regulation or exceeds the permitted use, you will need to obtain permission directly from the copyright holder. To view a copy of this licence, visit http://creativecommons.org/licenses/by/4.0/ The Creative Commons Public Domain Dedication waiver (http://creativecommons.org/publicdomain/zero/1.0/) applies to the data made available in this article, unless otherwise stated in a credit line to the data. 


\section{Background}

Bariatric Surgery (BS) has recently become of great interest in treating morbid obesity and obesity-related comorbidities such as metabolic syndrome, insulin resistance, and type 2 diabetes [1-5]. Roux-en-Y gastric bypass (RYGB) and sleeve gastrectomy (SG) are the most popular BS techniques worldwide [6, 7]. Despite the effectiveness of BS on losing weight and improving quality of life for morbid obese patients, nutritional deficiency, protein-calorie malnutrition, and muscle loss are of great concern since they may emerge due to changes in stomach volume, lack of nutrient intake, protein and solid foods intolerance, and malabsorption [8-16]. There is limited information about dietary intake evaluation after BS based on the global recommendation [12, 17-21]. Vanoh et al. showed that despite of supplementation the intake of vitamins $E$ and D, also zinc and calcium did not meet reference nutrient intake (RNI) [19]. Furthermore, patients may poorly observe the recommendations regarding the regular consumption of supplements. a literature review of 15 studies on Nutritional deficiency after SG showed that, despite of supplementation the incidence of vitamin B1, B6, B12, and calcium deficiency is common due to both malabsorption and food restriction pattern [22]. In some other cases, standard supplements sometimes is not sufficient to prevent nutritional deficiency [23, 24]. The present study mainly aimed to evaluate dietary intake adequacy of wide range of macronutrients and micronutrients based on the recommended standards at 6th and 12th month after BS. Also, assessing the nutrient density and comparison of nutrient intake changes between two intervals was the next points.

\section{Methods}

\section{Patient selection and anthropometric measurement}

This study was conducted in accordance with the framework of the Tehran obesity treatment study (TOTS), an ongoing single-institution prospective study initiated in
March, 2013 [25]. In our retrospective study, 161 severely obese subjects with the body mass index (BMI) $\geq 40 \mathrm{~kg} / \mathrm{m} 2$ or $40<\mathrm{BMI} \geq 35 \mathrm{~kg} / \mathrm{m}^{2}$ with at least one or more obesity-related co-morbidities undergoing BS during 2015 to 2016 were selected from the Tehran Obesity Treatment Center, 103 patients were not eligible to participate according to the exclusion criteria (Fig. 1). Fifty eight subjects undergoing either RYGB or SG were included in the present study. Sample size was calculated for at least 35 variables separately using sample size for comparing two dependent means, considering $\alpha=0.05$ and power $90 \%$; the mean calculated samples was 56 , only 7 variables were with calculated sample size of greater than 60 and $80 \%$ of variables had sample size lower than 60 . Hence, the present sample size of this study seems sufficient to generalize to people undergoing surgery, also previous studies had similar sample sizes $[10,20,26]$.

Anthropometric measurements were assessed before the surgery and at 6th and 12th month post-surgery in light clothes after overnight fasting. Moreover, BMI was calculated by dividing weight in $\mathrm{kg}$ by height in meters square, and the body composition analyzer in Body 370 (Biospace, Seoul, Korea) was used to measure the body fat percentage and fat free mass (FFM). Further, waist circumference (WC) and hip circumference were measured to the nearest $0.2 \mathrm{~cm}$ with a flexible measuring tape, and height was measured to the nearest $0.1 \mathrm{~cm}$ using a wallmounted stadiometer (Seca). The percentage of excess weight loss (\%EWL) was calculated by standard formula: (pre-operative weight - post-operative weight) / (pre-operative weight - ideal weight) $\times 100[15,19]$.

\section{Assessment of nutrient intake adequacy and nutrient density score}

DRI was used to analyze energy as well as macronutrient and micronutrient intakes [27], and the estimated average requirement (EAR) cut-point was used to estimate

161 severely obese patients were selected from Tehran Obesity Treatment Center.

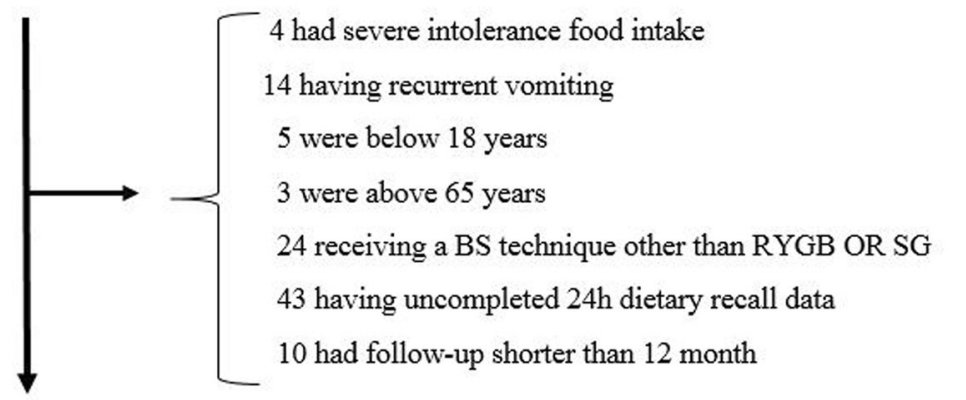

58 patients included in the analysis

Fig. 1 Patient selection criteria 
the nutrient intake adequacy $[27,28]$. Adequate Intakes (AI) was used for the micronutrients with no EAR value. Protein intake was assessed based on BS guideline recommendations [29-31]. The percentage distribution of the macronutrients with respect to total energy intake was assessed according to the acceptable macronutrient distribution ranges (AMDR). To assess the compliance of patients with dietary recommendations, dietary intakes were obtained using a three-day, 24-h dietary recall food questionnaire at the 6th and 12th month after BS (two non-consecutive weekdays and one weekend day). The questionnaire was filled out by a trained dietitian. The tables of the US Department of Agriculture [32] and the Iranian Food Composition [33] were used to convert crude data to grams, milligrams, or micrograms. The nutrient density score was also calculated to compare the rate of consuming healthy foods with lower energy density and higher nutrient-rich diets at the 6th and 12th month after the surgery. This score distinguishes nutrient-rich foods with high scores from high calories and poor-nutrients foods with low scores [34-36].

All the patients were scheduled for follow-up visits by a multidisciplinary team (ie, surgeon, obesity specialist, endocrinologist, and dietitian) at 10 days, and at 1, 3, 6, and 12 months after surgery. Our dietitian was responsible to consult the patients to follow healthy eating and dietary aspects of the regimen, including taking fresh fruits and vegetables, and elimination of sweetened beverages particularly for GB group to prevent dumping syndrome. Protein requirements was individualized according to gender, age, and weigh and should not be less than $60 \mathrm{~g} /$ day according to clinical practice guideline [29]. Daily Nutritional supplements were prescribed for all the patients according to ASMBS guideline, multivitamin Ecophan (Biorga) and Pharmaton (BoehringerIngelheim Inc. Ingelhem am Rhein, Germany) were prescribed in the month 6th and 12th after the surgery respectively. Calcicare as a calcium supplement was given to the GB group for a year, 1 tablet daily, containing $200 \mathrm{IU}$ vitamin D, $400 \mathrm{mg}$ Calcium, $100 \mathrm{mg}$ magnesium and $4 \mathrm{mg}$ Zinc per tablet [37].

\section{Statistical analysis}

Analysis was performed using SPSS version 20 (SPSS Inc., Chicago, Illinois). The quantitative variables were summarized as mean \pm standard deviation $(\mathrm{SD})$ for normal variables and median and range for non-normal variables. Qualitative data were reported as frequency and percentage. The Kolmogorov-Smirnov test was used to determine data normality. Paired-t-test as a parametric test was used for the variables with normal distribution, to examine the difference of anthropometric variables and the dietary nutrient intakes between the 6th and 12th month after BS, and Wilcoxon signed rank test was used as nonparametric test in case of the data did not have normal distribution.

\section{Results}

Of the 58 individuals participating in the study (RYGB $(N=16)$ and SG $(N=42)), 71 \%$ were female and $72 \%$ were married. The patients had a mean age of $37 \pm 8$ years. The mean weight, BMI, WC, and $\mathrm{HC}$ of the participants before the surgery were $120 \pm 21(\mathrm{~kg}), 44 \pm 6$ $(\mathrm{kg} / \mathrm{m} 2), 130 \pm 16(\mathrm{~cm})$, and $133 \pm 14(\mathrm{~cm})$, respectively.

\section{Anthropometric changes}

Table 1 shows the characteristic and anthropometric parameters of the study participants before and after BS. The statistical analysis revealed a significant decrease in the mean weight, BMI, and WC in the first and second 6 -month intervals for the post-surgery visit $(P<0.001)$. All the parameters decreased more rapidly during the first 6 months after BS. The percentage of body fat decreased significantly from $39 \pm 8$ to $34 \pm 9 \%$ at the 6th and 12th month after BS, $(P<0.001)$. The percentage of EWL was $>61 \pm 22$ at the 6th month and increased to $76 \pm 26$ at the 12th month after BS $(P<0.001)$.

\section{Macronutrient dietary intake changes and their adequacy}

As shown in Table 2, the nutrient density had a significant decrease from $0.63 \pm 0.20$ to $0.44 \pm 0.16$ between the 6th and 12th month after BS $(p<0.001)$; however, the amount of carbohydrate intake increased significantly between two intervals $(P=0.04)$. Protein intake was $45 \pm 30 \mathrm{~g} / \mathrm{d}$ at the 6th month and decreased dramatically to $31 \pm 15(\mathrm{~g} /$ day $)(P=0.002) 1$ year after the surgery.

At the 6th month after BS, $22.4 \%$ of the individuals had adequate protein intake according to the BS recommendation $[24,25]$ but experienced a significant decrease in this regard 1 year after BS. Accordingly, only $10.5 \%$ of the individuals had protein intake adequacy and $50 \%$ of the individuals received below $29 \mathrm{~g}$ protein from foods.

The percentage of total dietary fat and n-6 PUFA intake revealed no significant difference at the both intervals, whereas SFA intake decreased dramatically between the 6th and 12th month after the surgery $(P=0.02)$ and $50 \%$ of individuals observed the recommendations and received $<10 \%$ of daily energy intake. Among the participants, the percentage of n3-PUFA from total energy intake increased significantly from $0.4 \pm 0.2 \%$ to $0.8 \pm 1.2 \%$ at the 6th and 12th month after the surgery $(P=0.02)$. Although, $<30 \%$ of the individuals had adequate intake at the both intervals. The median intake of fiber was $10.1 \pm 8.7 \mathrm{~g} / \mathrm{d}$ at the 6 th month, which was significantly reduced to $6.9 \pm 5.7 \mathrm{~g} / \mathrm{d}$ a year after the surgery $(P=$ 
Table 1 Characteristic and anthropometric parameters of the study participants before and after BS

\begin{tabular}{|c|c|c|c|c|}
\hline & Pre-operation $n=58$ & Post operat & & $p_{\text {value }}$ \\
\hline & Baseline & 6th month & 12th month & \\
\hline Age & $37 \pm 8$ & - & - & \\
\hline Gender (female) & $71 \%$ & - & - & \\
\hline Weight (kg) & $120 \pm 21$ & $89 \pm 17$ & $83 \pm 18$ & $<0.001$ \\
\hline BMI $\left(\mathrm{Kg} / \mathrm{m}^{2}\right)$ & $44 \pm 6$ & $33 \pm 6$ & $31 \pm 6$ & $<0.001$ \\
\hline WC (cm) & $130 \pm 16$ & $106 \pm 13$ & $98 \pm 13$ & $<0.001$ \\
\hline $\mathrm{HC}(\mathrm{cm})$ & $133 \pm 14$ & $115 \pm 14$ & $110 \pm 10$ & $<0.001$ \\
\hline FFM (\%) & $62 \pm 11$ & $53 \pm 10$ & $52 \pm 10$ & $<0.100$ \\
\hline Body Fat (\%) & $49 \pm 3$ & $39 \pm 8$ & $34 \pm 9$ & $<0.001$ \\
\hline Excess weight loss (\%) & - & $61 \pm 22$ & $76 \pm 25$ & $<0.001$ \\
\hline
\end{tabular}

Data are presented as mean \pm SD. $P$-value derived from paired t-test for numerical variables between the 6 and 12 month. BMI Body mass index, WC Waist circumference, HC Hip Circumference, FFM Fat-Free Mass

0.001). Fiber was the only macronutrient which was taken by none of the individuals according to the recommendations and $50 \%$ of population received $<9 \mathrm{~g}$ of fiber in both intervals (Table 2).

\section{Dietary micronutrient intake changes and adequacy}

As shown in Table 3, out of the 21 micronutrients, the dietary intake of $90 \%$ of nutrients had significant decreased between the 6th and 12th months after the surgery $(P<0.05)$. The dietary intakes of biotin $\left(B_{7}\right)$, fat soluble vitamins, niacin $\left(B_{3}\right)$, pantothenic acid $\left(B_{5}\right)$, pyridoxine $\left(\mathrm{B}_{6}\right)$, thiamin $\left(\mathrm{B}_{1}\right)$, as well as minerals such as calcium, copper, iron, potassium and phosphorus were extremely lower than the standard level at the both intervals. Of the participants undergoing BS, $\geq 98$ showed inadequate nutrient intake in terms of biotin $\left(B_{7}\right)$, fat soluble vitamins, pantothenic acid $\left(\mathrm{B}_{5}\right)$, potassium, and zinc $(\mathrm{Zn})$, at 6th and 12th month after BS. Moreover, less than $10 \%$ of the individuals received calcium $(\mathrm{Ca})$, folic acid (B9), magnesium (Mg), and manganese (Mn) according to the EAR or AI recommendations. Six months after the surgery, $\geq 65 \%$ of the participants had thiamin, riboflavin, pyridoxine, copper, and iron intakes below the recommended levels. This percentage increased up to $>90 \%$ for pyridoxine and thiamin and $>$ $75 \%$ for copper, iron, and riboflavin 1 year after the surgery. Six months after BS, $50.4 \%$ of the patients had

Table 2 Daily dietary intake of energy and macronutrients and percent of individuals had adequacy intake at the 6th and 12th month post-Bariatric Surgery compared to dietary recommendations

\begin{tabular}{|c|c|c|c|c|c|c|}
\hline \multirow[t]{2}{*}{ Variables } & \multirow[t]{2}{*}{ Reference $^{b}$} & \multicolumn{2}{|c|}{ Post-operation $^{c}(n=58)$} & \multirow[t]{2}{*}{$P$-value } & \multicolumn{2}{|c|}{ Adequacy $^{f}$} \\
\hline & & 6 month & 12 month & & 6 month & 12 month \\
\hline Total energy (kcal/day) & - & $924(3069)$ & $1048(2255)$ & $0.057^{d}$ & - & - \\
\hline Nutrient Density (\%) ${ }^{a}$ & - & $0.63 \pm 0.20$ & $0.44 \pm 0.16$ & $<0.001^{e}$ & - & - \\
\hline Carbohydrate (\% of energy) & $45-56$ & $48 \pm 12$ & $53 \pm 16$ & $0.04^{e}$ & 100 & 100 \\
\hline Protein $(\mathrm{g} / \mathrm{d})$ & $60^{g}$ & $45 \pm 30$ & $31 \pm 15$ & $0.002^{e}$ & 22.4 & 10.5 \\
\hline Total Fat (\% of energy) & $20-35$ & $36(47)$ & $36(65)$ & $0.92^{d}$ & 44.8 & 34.5 \\
\hline SFA (\% of energy) & $<10$ & $15 \pm 5$ & $10 \pm 5$ & $0.02^{e}$ & 55.4 & 51.8 \\
\hline Linoleic acid (g/d) & $11-17$ & $4.2(23)$ & $4.0(22)$ & $0.997^{d}$ & 7.0 & 14 \\
\hline n3-PUFA (\% of energy) & $0.6-1.2$ & $0.3(1.0)$ & $0.4(5.8)$ & $0.02^{d}$ & 17.5 & 28.1 \\
\hline n6-PUFA (\% of energy) & $5-10$ & $5.5(15)$ & $5.6(35)$ & $0.651^{d}$ & 61.4 & 60.7 \\
\hline Fiber (g/d) & $25-38$ & $8.7(31)$ & $5.7(25)$ & $0.001^{d}$ & 0 & 0 \\
\hline
\end{tabular}

a.This score distinguishes nutrient-rich foods with high scores from foods with high calories and few nutrients with lower score b.Dietary Reference Intake (DRI)

c. Data are presented as median (range) or mean \pm SD according to normal and non-normal distribution respectively

d. P-value derived from Wilcoxon test for variables do not follow a normal distribution

e. $P$-value derived from paired t-test for normally distributed variables

f. The percent of individuals who had compliance with standard recommendation

g. The reference has considered based on BS Guide Lines protein recommendation 
Table 3 Comparison of the dietary intakes and the percent of individuals with a dietary intake below the recommendations at the 6th and 12th months post-Bariatric Surgery

\begin{tabular}{|c|c|c|c|c|c|c|}
\hline \multirow{2}{*}{$\begin{array}{l}\text { Variables } \\
\text { Vitamins }\end{array}$} & \multirow[t]{2}{*}{$\begin{array}{l}\text { References } \\
\mathbf{a}\end{array}$} & \multicolumn{2}{|c|}{$\begin{array}{l}\text { Post-operation }{ }^{b} \\
(n=58)\end{array}$} & \multirow[t]{2}{*}{$p_{\text {value }}$} & \multicolumn{2}{|c|}{$\%$ of inadequacy $^{e}$} \\
\hline & & 6 month & 12 month & & 6 month & 12 month \\
\hline Biotin (B7) $\mu \mathrm{g} / \mathrm{d}$ & $25-30$ & $7.1(29)$ & $5.8(30)$ & $0.04^{c}$ & 100 & 98.2 \\
\hline Cobalamin (B12) $\mu \mathrm{g} / \mathrm{d}$ & 2.0 & $1.8(3.8)$ & $1.3(3.9)$ & $0.001^{c}$ & 54.4 & 77.2 \\
\hline Folate (B9) $\mu \mathrm{g} / \mathrm{d}$ & $320-330$ & $121(484)$ & 102(496) & $0.046^{c}$ & 93 & 96.5 \\
\hline Niacin (B3) mg/d & $11-12$ & $11.3(36)$ & $6.9(30)$ & $0.001^{c}$ & 47.4 & 71.9 \\
\hline Pantothenic acid (B5) mg/d & 5 & $1.7(4.3)$ & $1.1(4.5)$ & $0.001^{c}$ & 100 & 100 \\
\hline Pyridoxine (B6) mg/d & $1-1.4$ & $0.9 \pm 0.5$ & $0.5 \pm 0.4$ & $<0.001^{d}$ & 64.9 & 99.9 \\
\hline Riboflavin (B2) mg/d & $0.9-1.0$ & $0.63(2.5)$ & $0.52(2.7)$ & $0.033^{c}$ & 77.2 & 78.9 \\
\hline Thiamin (B1) $\mathrm{mg} / \mathrm{d}$ & $0.9-1.0$ & $0.54(1.6)$ & $0.44(1.4)$ & $0.010^{c}$ & 86 & 91.2 \\
\hline Vitamin $A_{\mu g / d}$ & $625-630$ & $185 \pm 144$ & $110 \pm 90$ & $0.001^{d}$ & 99.2 & 100 \\
\hline Vitamin $C_{\mathrm{mg} / \mathrm{d}}$ & $56-75$ & $61.8(193)$ & $16.7(110)$ & $<0.001^{c}$ & 50.4 & 99.9 \\
\hline Vitamin $D_{\mu g / d}$ & 10 & $0.60(2.6)$ & $0.08(1.8)$ & $<0.001^{c}$ & 100 & 100 \\
\hline Vitamin $\mathrm{E}_{\mathrm{mg} / \mathrm{d}}$ & 12 & $4.0 \pm 3.8$ & $4.6 \pm 4.6$ & $0.061^{d}$ & 100 & 86 \\
\hline Vitamin $K_{\mu g / d}$ & $75-120$ & $21(158)$ & $18(123)$ & $0.04^{c}$ & 100 & 100 \\
\hline \multicolumn{7}{|l|}{ Minerals } \\
\hline Calcium (Ca) mg/d & $800-1100$ & $293(985)$ & $171(799)$ & $0.001^{c}$ & 93 & 98.2 \\
\hline Copper $(\mathrm{Cu})_{\mu \mathrm{g} / \mathrm{d}}$ & $685-700$ & $537(1737)$ & $356(1621)$ & $0.002^{c}$ & 68.4 & 76.8 \\
\hline Iron $(\mathrm{Fe}) \mathrm{mg} / \mathrm{d}$ & $6.0-8.1$ & $5.2(12)$ & $4.6(11)$ & $0.014^{c}$ & 68.4 & 80.7 \\
\hline Magnesium $(\mathrm{Mg}) \mathrm{mg} / \mathrm{d}$ & $255-340$ & $115(320)$ & 89 (339) & $0.013^{c}$ & 98.2 & 98.2 \\
\hline Manganese $(\mathrm{Mn}) \mathrm{mg} / \mathrm{d}$ & $1.6-2.2$ & $0.88(3.1)$ & $0.91(4.2)$ & $0.974^{c}$ & 96.5 & 91.2 \\
\hline Phosphorus (P) mg/d & 580-1055 & $573(1313)$ & $441(1088)$ & $0.003^{c}$ & 50 & 71.4 \\
\hline Potassium (K) $\mathrm{g} / \mathrm{d}$ & 4.7 & $1.3 \pm 0.6$ & $0.9 \pm 0.5$ & $<0.001^{d}$ & 100 & 100 \\
\hline Zinc $(Z n) \mathrm{mg} / \mathrm{d}$ & $6.8-9.4$ & $3.9(7.4)$ & $3.2(12.3)$ & $0.009^{c}$ & 99.9 & 99.9 \\
\hline
\end{tabular}

aAR (An Estimated Average Requirement) is the average daily nutrient intake level estimated to meet the requirements of half of the healthy individuals in a group. EARs have not been established for vitamin K, pantothenic acid, biotin, manganese, and potassium, in this case Al (adequate intake) has been set. The cut point is adjusted for aged between 18 and 65 year; $\mu \mathrm{g} / \mathrm{d}$ : microgram per day; $\mathrm{mg} / \mathrm{d}$ : milligram per day

${ }^{\circ}$ Data are presented as median (range) or mean \pm SD according to normal and non-normal distribution respectively

${ }^{\mathrm{C} P}$ value derived from Wilcoxon test for variables do not follow a normal distribution

${ }^{\mathrm{d}} \mathrm{P}$-value derived from paired t-test for normally distributed variables

'The percent of individuals who had inadequate intake

inadequate dietary intake for ascorbic acid, which increased to more than $99.9 \% 1$ year after the surgery $(P<$ 0.001). It suggests that less than $10 \%$ of the participants had dietary intake according EAR 1 year after BS.

\section{Discussion}

This study evaluated the dietary intake adequacy of macronutrients and a wide range of micronutrients at the 6th and 12th month after BS and assessed the changes between two intervals. The findings showed that the percentages of carbohydrate and fat intake from energy were higher than the recommendations, and the percentage of carbohydrate intake increased significantly from 6th to 12th month after BS which is in contrast to the guideline claimed that to prevent weight regain in a short-term period, $40-45$ and $<20 \%$ of calories should be provided from carbohydrates and fats 1 year after the surgery, respectively [29]. Also, the nutrient density score decreased dramatically between two intervals, it seems that the patients received high calorie poornutrients foods. Moreover, protein intake was observed to be lower than the recommended level at both intervals. According to previous studies, for patients undergoing BS, at least $60 \mathrm{~g} /$ day protein is adequate and $80-90 \mathrm{~g} /$ day protein is needed to prevent loss of lean body mass [29, 31]. Also, Heber et al., documented that patients should consume $30 \mathrm{~g}$ of protein in more than one meal per day to prevent bone and muscle insufficiencies [38]. In the present study, $77.6 \%$ of the participants had a protein intake below the standard $(60 \mathrm{~g} / \mathrm{d})$ at month 6, and this value increased to $89.5 \% 1$ year after BS. The results showed that $50 \%$ of population receive 39 and $29 \mathrm{~g}$ protein per day at the 6th and 12th month after surgery respectively. Our findings are in line with 
those of Mechanick, Andreu, and Moize et al. They showed that 61,37 , and $46 \%$ of the participants had protein intake $<60 \mathrm{~g} /$ day 1 year after BS [12, 39, 40]. In our study, the prevalence (\%) of the patients with insufficient protein intake was approximately three times as large as the one reported by Andreu et al. 12 months after surgery [39]. The low protein intake adequacy may be the result of severe food restrictions caused by the small volume of the stomach and intolerance to protein-rich foods occurring 1 year after BS [14, 15, 41]. In our study, none of the participants could consume fiber according to recommendations. Low fiber intake is probably associated with low intake of vegetables and fruits due to the mechanical restriction imposed by the surgery. This finding is similar to the finding of Novais et al. who showed that participants' dietary fiber intake was extremely low in accordance to the AI recommendations [18]. In the present study, the dietary intake of most micronutrients could not meet the EAR value at both intervals assessments and had significant decreased from the 6th to 12th month after BS. This is in contrast with data reported by Andrue et al. showed dietary intake increased gradually through a year post- BS [26]. The nutrients with severe low dietary intake were biotin, calcium, folate, pantothenic acid, fat soluble vitamins, vitamin $C$, potassium and magnesium which $50 \%$ of the population received $\leq 35 \%$ from the minimum EAR or AI 1 year after BS and more than $95 \%$ of patients could not meet the recommendations. Moreover, 77.2 and $80.7 \%$ of subjects showed inadequacy, In terms of cobalamin and iron intake respectively. The low dietary intake of iron and vitamin B12 was in line with previous studies $[26,42]$. The high inadequacy might be related to the lower tolerance to meat, fish, dairy products, egg yolk, green leafy vegetables, nuts and seeds as the main source of these micronutrients. Similar to previous studies, the median intake of vitamin $C$ was significantly decreased 1 year after surgery, and more than $99 \%$ of the participants had a vitamin $C$ intake below EAR at the 12th month after BS. The high inadequacy of dietary vitamin $C$ intake was in line with the findings of the previous studies $[26,42]$ and might be caused by the low quality of the diet with limited fruit and vegetable intake during the surgery follow-up period. As a matter of fact, after BS, patients need to be adjusted to the change in the gastric volume and tolerance for food, especially during the first year after the surgery. Wisnewsky et al., showed patients displayed a significant 2-fold decrease in food ingestion speed after BS [17]. Moreover, changes in eating behavior after BS like vomiting, difficult to swallowing due to texture, plugging (sense of food, particularly meat and bread becoming stuck in the upper digestive tract), reported as the barriers to food intake $[43,44]$. Nutrient adequacy highly depended on food choices, food texture, and speed of food ingestion, volume and frequency of meal. The texture of foods provide patients to have better ingestion and digestion. Hence, following a proper and tolerable diet containing lean meat, poultry, fish, and legume in the blended form, also, pureed form of fruits and vegetables, fruit milk shake or fruit and yogurt smoothie with wheat germ/nut powder, soup prepared with bone broth and natural vegetable extracts can help the patients receive much micronutrients, fiber, protein, complex carbohydrates, and healthy sources of essential fatty acids naturally. This can promote a healthy short and long-term postoperative dietary pattern to prevent nutritional deficiency.

Furthermore, due to the low capacity of the stomach, the patients need to take high protein -low carbohydrate ready to use formula or drink enriched with vitamins and minerals specified for these groups to promote maximum adherence to their diet, patients undergoing BS are more susceptible to protein malnutrition [45-47], Schollenberger and Batar et al. showed that taking protein supplement can improve body composition by preventing FFM loss and enhancing loss of body fat [48, 49].

Recent studies have revealed that despite of supplementation, deficiency of cobalamin (vitamin B12), calcium, folate, fat soluble vitamins, thiamin and vitamin D is common after BS [22, 50-52]. Bariatric surgery are also associated with the risk for neurological complications (Wernicke encephalopathy and Korsakoffsyndrome) due to both shortage in dietary intake and non-compliance of vitamin supplementation [53, 54]. Researchers have claimed that supplement therapy may not be sufficient to prevent nutrient deficiency, the reasons are: prescribed supplements may not cover all target nutrients for individuals undergoing BS, moreover, recommended dosage may be insufficient, especially for those with malabsorptive operation (RYGB) [24], and patients may not regularly take supplement. Modi et al. showed that forgetting and difficulty swallowing supplement were the two main barriers identified for patients who had undergone BS [23]. Previous studies showed, numerous bioactive foods components (Apigenin, Allicin, Genistein, Luteolin, Lycopene, Myricetin, Quercetin, Resveratrol, Vitamins) can prevent cardiovascular disease and cancer [55-61]. These components are easily accessible in healthy foods mainly in fruits, vegetables, and whole grains [62]. Accordingly increasing the quality of their diet should be considered to promote individuals functional health. Registered dietitians are responsible to provide patients a practical dietetic recommendations according to the type of surgery and plan a proper diet based on the most common deficiencies according to the guideline like ASMBS to provide patient to meet nutrients intake from both foods and supplements [37]. 
Monitoring of patients in a shorter follow up period even monthly would be beneficial to provide them maximum adherence to the diet and supplements.

The main limitation of the present study was that there was insufficient data regarding the measurement of serum biochemical parameters before and after the surgery. Also, Lack of data in terms of preoperative food intake. A small sample size was another limitation of the study. Moreover, fewer Roux-En-Y patients $(N=16)$ than sleeve group $(N=42)$ was main barrier to do analyze between group. However, our study is outstanding for 1: assessing the dietary intake of a wide range of micronutrients and macronutrients according to the standards at the 6th and 12th month after BS and between two intervals. 2: evaluating nutrient density to distinguish healthy nutrient-rich foods from high-calorie and poor-nutrient foods.

\section{Conclusions}

According to our findings, the dietary intake of protein, fiber, and nearly all the micronutrient especially biotin, calcium, folate, pantothenic acid, fat soluble vitamins, vitamin $C$, potassium and magnesium was significantly lower than EAR and significantly decreased between the 6th and 12month after BS. Eating a healthy, high quality tolerable diet is more important in the short and long time after the surgery because this operation has been done forever and it is expected the patients have adherence to both diet and supplements.

\section{Abbreviations}

BS: Bariatric Surgery; DRIs: Dietary Reference Intakes; RYGB: Roux-en-Y Gastric Bypass; SG: Sleeve Gastrectomy; RDA: Recommended Dietary Allowance; RNI: Reference Nutrient Intake; TOTS: Tehran Obesity Treatment Study; BMI: Body Mass Index; FFM: Fat Free Mass; WC: Waist Circumference; HC: Hip Circumference; EWL: Excess Weight Loss; EAR: Estimated Average Requirement; AMDR: Acceptable Macronutrient Distribution Ranges

\section{Acknowledgements}

The authors are thankful to all patients for assistance in completing the $24 \mathrm{~h}$ dietary recall questionnaire. Moreover, we would like to avail this opportunity to thank Dr. Elahe Kazemi, Ph.D. of Biostatistics and Ms. Maryam Mahdavi for their scientific comments and contribution in data analysis.

\section{Authors' contributions}

MZ: designing the frame work, gathering and entering the data into SPSS, analyzing the data and interpreting results, writing the main manuscript and designing the tables, revising and editing the manuscript, and reading and approving the final manuscript; $\mathrm{FH}$ : contributing to designing and analyzing the data, revising and editing the manuscript, contributing to interpreting the results, reading and approving the final manuscript; HM-Kh: directing the project, contributing to interpreting the results, and revising and approving the manuscript; F-HP: revising the manuscript critically for important intellectual content and contributing to interpreting the results; reading and approving the final manuscript; MB: providing access to the patients' clinical data, and revising the manuscript; reading and approving the final manuscript; A-Kh: Contributing as a surgeon, providing access to the patients' clinical data, and revising the manuscript; reading and approving the final manuscript; MV: supporting and helping during the work, contributing to planning and supervising the project, interpreting the data, revising the manuscript, and approving the final manuscript for publication. The author(s) read and approved the final manuscript.

\section{Funding}

No funding was obtained for this study.

\section{Availability of data and materials}

The datasets used and analyzed in the present study are at the disposal of the corresponding Author and are available on reasonable request.

\section{Ethics approval and consent to participate}

All the procedures performed in the present study, including participant selection, were approved and coded by the Ethics Committee of the Research Institute for Endocrine Sciences at the Shahid Beheshti University of Medical Sciences, Tehran, Iran.(IR.SBMU.ENDOCRINE.REC.1395.203).

\section{Consent for publication}

Not applicable.

\section{Competing interests}

The authors declare that they have no competing interests.

\section{Author details}

${ }^{1}$ International Campus of Shahid Sadoughi University of Medical Sciences, Yazd, Iran. ${ }^{2}$ Nutrition and Endocrine Research Center, Research Institute for Endocrine Sciences, Shahid Beheshti University of Medical Science, Tehran, Iran. ${ }^{3}$ Department of Nutrition, School of Public Health, Shahid Sadoughi University of Medical Sciences, Yazd, Iran. ${ }^{4}$ Obesity Research Center, Research Institute for Endocrine Science, Shahid Beheshti University of Medical Sciences, Tehran, IR, Iran. ${ }^{5}$ Obesity Treatment Center, Department of Surgery, Faculty of Medicine, Shahed University, Tehran, Iran.

Received: 13 April 2020 Accepted: 23 September 2020

Published online: 12 October 2020

\section{References}

1. Haruta H, Kasama K, Ohta M, Sasaki A, Yamamoto H, Miyazaki Y, et al. Longterm outcomes of bariatric and metabolic surgery in Japan: results of a multi-institutional survey. Obes Surg. 2016;8:8.

2. Wentworth JM, Playfair J, Laurie C, Ritchie ME, Brown WA, Burton P, et al. Multidisciplinary diabetes care with and without bariatric surgery in overweight people: a randomised controlled trial. Lancet Diabetes Endocrinol. 2014;2(7):545-52 PubMed PMID: 24731535. Epub 2014/04/16. eng.

3. Wu GZ, Cai B, Yu F, Fang Z, Fu XL, Zhou HS, et al. Meta-analysis of bariatric surgery versus non-surgical treatment for type 2 diabetes mellitus. Oncotarget. 2016;10(10):11961.

4. Batsis JA, Romero-Corral A, Collazo-Clavell ML, Sarr MG, Somers VK, LopezJimenez F. Effect of bariatric surgery on the metabolic syndrome: a population-based, long-term controlled study. Mayo Clin Proc. 2008;83(8): 897-907.

5. Ikramuddin S, Korner J, Lee WJ, Bantle JP, Thomas AJ, Connett JE, et al. Durability of addition of roux-en-Y gastric bypass to lifestyle intervention and medical Management in Achieving Primary Treatment Goals for uncontrolled type 2 diabetes in mild to moderate obesity: a randomized control trial. Diabetes Care. 2016;39(9):1510-8.

6. Angrisani L, Santonicola A, lovino P, Formisano G, Buchwald H, Scopinaro N. Bariatric surgery worldwide 2013. Obes Surg. 2015;25(10):1822-32.

7. Buchwald H, Oien DM. Metabolic/bariatric surgery worldwide; 2011.

8. Fujioka K. Follow-up of nutritional and metabolic problems after bariatric surgery. Diabetes Care. 2005;28(2):481-4.

9. Shikora SA, Kim JJ, Tarnoff ME. Nutrition and gastrointestinal complications of bariatric surgery. Nutr Clin Pract. 2007;22(1):29-40.

10. Coupaye M, Riviere P, Breuil MC, Castel B, Bogard C, Dupre T, et al. Comparison of nutritional status during the first year after sleeve gastrectomy and roux-en-Y gastric bypass. Obes Surg. 2014;24(2):276-83.

11. Moize V, Andreu A, Flores L, Torres F, Ibarzabal A, Delgado S, et al. Longterm dietary intake and nutritional deficiencies following sleeve gastrectomy or roux-en-Y gastric bypass in a mediterranean population. J Acad Nutr Diet. 2013;113(3):400-10.

12. Verger EO, Aron-Wisnewsky J, Dao MC, Kayser BD, Oppert JM, Bouillot JL, et al. Micronutrient and protein deficiencies after gastric bypass and sleeve Gastrectomy: a 1-year follow-up. Obes Surg. 2016;26(4):785-96. 
13. Weng TC, Chang CH, Dong YH, Chang YC, Chuang LM. Anaemia and related nutrient deficiencies after roux-en-Y gastric bypass surgery: a systematic review and meta-analysis. BMJ Open. 2015;5(7):2014-006964.

14. Nicoletti CF, de Oliveira BAP, Barbin R, Marchini JS, Junior WS, Nonino CB. Red meat intolerance in patients submitted to gastric bypass: a 4-year follow-up study. Surg Obes Relat Dis. 2015;11(4):842-6.

15. Moizé V, Geliebter A, Gluck ME, Yahav E, Lorence $M$, et al. Obese patients have inadequate protein intake related to protein intolerance up to 1 year following roux-en-Y gastric bypass. Obes Surg. 2003;13(1):23-8.

16. Mohapatra S, Gangadharan K, Pitchumoni CS. Malnutrition in obesity before and after bariatric surgery. Disease-a-Month. 2020;66(2):100866.

17. Aron-Wisnewsky J, Verger EO, Bounaix C, Dao MC, Oppert JM, Bouillot JL, et al. Nutritional and Protein Deficiencies in the Short Term following Both Gastric Bypass and Gastric Banding. PLoS One. 2016;11(2):e0149588.

18. Novais PF, Rasera I Jr, Leite CV, Marin FA, de Oliveira MR. Food intake in women two years or more after bariatric surgery meets adequate intake requirements. Nutr Res. 2012;32(5):335-41.

19. Vanoh D, Shahar S, Mahmood NR. Association between nutrient adequacy and psychosocial factors with overall rate of weight loss after bariatric surgery. Asia Pac J Clin Nutr. 2015;24(4):610-9.

20. LEIRO LS, Melendez-ARAÚJO MS. Diet micronutrient adequacy of women after 1 year of gastric bypass. Arq Bras Cir Dig. 2014;27:21-5.

21. Jeffreys RM, Hrovat K, Woo JG, Schmidt M, Inge TH, Xanthakos SA. Dietary assessment of adolescents undergoing laparoscopic roux-en-Y gastric bypass surgery: macro-and micronutrient, fiber, and supplement intake. Surg Obes Relat Dis. 2012;8(3):331-6.

22. Emile $\mathrm{SH}$, Elfeki H. Nutritional deficiency after sleeve gastrectomy: a comprehensive. gastroenterology; 2017.

23. Modi AC, Zeller MH, Xanthakos SA, Jenkins TM, Inge TH. Adherence to vitamin supplementation following adolescent bariatric surgery. Obesity. 2013;21(3):E190-E5 PubMed PMID: 23404956. Pubmed Central PMCID: PMC3630236. Epub 2013/02/14. eng.

24. Gasteyger C, Suter M, Gaillard RC, Giusti V. Nutritional deficiencies after rouxen-Y gastric bypass for morbid obesity often cannot be prevented by standard multivitamin supplementation. Am J Clin Nutr. 2008;87(5):1128-33.

25. Barzin M, Hosseinpanah F, Motamedi MA, Shapoori P, Arian P, Daneshpour MA, et al. Bariatric Surgery for Morbid Obesity: Tehran Obesity Treatment Study (TOTS) Rationale and Study Design. JMIR Res Protoc. 2016:5(1):e8.

26. Gesquiere I, Foulon V, Augustijns P, Gils A, Lannoo M, Van der Schueren B, et al. Micronutrient intake, from diet and supplements, and association with status markers in pre- and post-RYGB patients. Clin Nutr. 2016;23(16):30206-0.

27. Trumbo P, Schlicker S, Yates AA, Poos M. Dietary reference intakes for energy, carbohydrate, fiber, fat, fatty acids, cholesterol, protein and amino acids. J Am Diet Assoc. 2002;102(11):1621-30 PubMed PMID: 12449285. Epub 2002/11/27. eng.

28. de Lauzon B, JV MA. A Monte Carlo simulation to validate the EAR cut-point method for assessing the prevalence of nutrient inadequacy at the population level; 2004.

29. Mechanick Jl, Youdim A, Jones DB, Garvey WT, Hurley DL, McMahon MM, et al. Clinical practice guidelines for the perioperative nutritional, metabolic, and nonsurgical support of the bariatric surgery patient--2013 update: cosponsored by American Association of Clinical Endocrinologists, the Obesity Society, and American Society for Metabolic \& bariatric surgery. Obesity. 2013;21(1):20461.

30. Jastrzebska-Mierzynska M, Ostrowska L, Wasiluk D, KonarzewskaDuchnowska E. Dietetic recommendations after bariatric procedures in the light of the new guidelines regarding metabolic and bariatric surgery. Rocz Panstw Zakl Hig. 2015;66(1):13-9.

31. Moizé VL, Pi-Sunyer $X$, Mochari H, Vidal J. Nutritional pyramid for postgastric bypass patients. Obes Surg. 2010;20(8):1133-41.

32. Food composition table (FCT). Food and Nutrition Information Center, US Department of Agriculture, Available from: www.nal.usda.gov/fnic/ foodcomp. 2010 [20 September 2009].

33. Azar MS. Food composition table of Iran. Tehran: National Nutrition and Food Research Institute of Shaheed Beheshti University; 1980

34. Drewnowski A, Fulgoni VL, 3rd. Nutrient density: principles and evaluation tools. Am J Clin Nutr 2014;99(5 Suppl):1223S-1228S. PubMed PMID: 24646818. Epub 2014/03/22. eng.

35. Drewnowski A, Dwyer J, King JC, Weaver CM. A proposed nutrient density score that includes food groups and nutrients to better align with dietary guidance. Nutr Rev. 2019;77(6):404-16 PubMed PMID: 31222368. Pubmed Central PMCID: PMC6489166. Epub 2019/06/22. eng.

36. Drewnowski A. Concept of a nutritious food: toward a nutrient density score. Am J Clin Nutr 2005;82(4):721-732. PubMed PMID: 16210699. Epub 2005/10/08. eng.

37. Parrott J, Frank L, Rabena R, Craggs-Dino L, IsomKA GL. American Society for Metabolic and Bariatric Surgery Integrated Health Nutritional Guidelines for the surgical weight loss patient. Surg Obes Relat Dis. 2017;13(5):727-41.

38. Heber D, Greenway FL, Kaplan LM, Livingston E, Salvador J, Still C. Endocrine and nutritional management of the post-bariatric surgery patient: an Endocrine Society clinical practice guideline. J Clin Endocrinol Metab. 2010; 95(11):4823-43 PubMed PMID: 21051578. Epub 2010/11/06. eng.

39. Andreu A, Moize V, Rodriguez L, Flores L, Vidal J. Protein intake, body composition, and protein status following bariatric surgery. Obes Surg. 2010; 20(11):1509-15.

40. Moize V, Andreu A, Rodriguez L, Flores L, Ibarzabal A, Lacy A, et al. Protein intake and lean tissue mass retention following bariatric surgery. Clin Nutr. 2013;32(4):550-5.

41. Bock MA. Roux-en-Y gastric bypass: the dietitian's and patient's perspectives Nutr Clin Pract. 2003;18(2):141-4.

42. Miller GD, Norris A, Fernandez A. Changes in nutrients and food groups intake following laparoscopic roux-en-Y gastric bypass (RYGB). Obes Surg. 2014;24(11):1926-32.

43. Sarwer DB, Dilks RJ, West-Smith L. Dietary intake and eating behavior after bariatric surgery: threats to weight loss maintenance and strategies for success. Surg Obes Relat Dis. 2011;7(5):644-51.

44. Kalarchian MA, Marcus MD, Courcoulas AP, Cheng Y, Levine MD. Self-report of gastrointestinal side effects after bariatric surgery. Surg Obes Relat Dis. 2014;10(6):1202-7.

45. Suarez Llanos JP, Fuentes Ferrer M, Alvarez-Sala-Walther L, Garcia Bray B, Medina Gonzalez L, Breton Lesmes I, et al. Protein malnutrition incidence comparison after gastric bypass versus Biliopancreatic diversion. Nutr Hosp. 2015;32(1):80-6.

46. Martins Tde C, Duarte TC, Mosca ER, Pinheiro Cde F, Marcola MA, De-Souza DA. Severe protein malnutrition in a morbidly obese patient after bariatric surgery. Nutrition. 2015;31(3):535-8 PubMed PMID: 25701346. Epub 2015/ 02/24. eng.

47. Faintuch J, Matsuda M, Cruz ME, Silva MM, Teivelis MP, Garrido AB Jr, et al, Severe protein-calorie malnutrition after bariatric procedures. Obes Surg. 2004:14(2):175-81.

48. Schollenberger AE, Karschin J, Meile T, Küper MA, Königsrainer A, Bischoff SC. Impact of protein supplementation after bariatric surgery: a randomized controlled double-blind pilot study. Nutrition. 2016;32(2):186-92.

49. Batar N, Üzel M. Comparıson of Weight and Body Compositıon Change in Person Usıng and Non-Usıng Proteın Powder In the First 6 Months Perıod after Barrier Surgery. Diabetes \& its Complications. 2018;2(1).

50. Bloomberg RD, Fleishman A, Nalle JE, Herron DM, Kini S. Nutritional deficiencies following bariatric surgery: what have we learned? Obes Surg. 2005;15(2):145-54

51. Bernert CP, Ciangura C, Coupaye M, Czernichow S, Bouillot J, Basdevant A. Nutritional deficiency after gastric bypass: diagnosis, prevention and treatment. Diabetes Metab. 2007;33(1):13-24.

52. Ben-Porat T, Elazary R, Yuval JB, Wieder A, Khalaileh A, Weiss R. Nutritional deficiencies after sleeve gastrectomy: can they be predicted preoperatively? Surg Obes Relat Dis. 2015;11(5):1029-36.

53. Punchai S, Hanipah ZN, Meister KM, Schauer PR, Brethauer SA, Aminian A. Neurologic manifestations of vitamin B deficiency after bariatric surgery. Obes Surg. 2017;27(8):2079-82.

54. Kröll D, Laimer M, Borbély YM, Laederach K, Candinas D, Nett PC. Wernicke encephalopathy: a future problem even after sleeve gastrectomy? A systematic literature review. Obes Surg. 2016;26(1):205-12.

55. Stefanska B, Karlic H, Varga F, Fabianowska-Majewska K, Haslberger A. Epigenetic mechanisms in anti-cancer actions of bioactive food components-the implications in cancer prevention. Br J Pharmacol. 2012; 167(2):279-97.

56. Kim YS, Young MR, Bobe G, Colburn NH, Milner JA. Bioactive food components, inflammatory targets, and cancer prevention. Cancer Prev Res. 2009;2(3):200-8.

57. Watson RR, Preedy VR. Bioactive foods in promoting health: fruits and vegetables: academic press; 2009. 
58. Stan SD, Kar S, Stoner GD, Singh SV. Bioactive food components and cancer risk reduction. J Cell Biochem. 2008;104(1):339-56.

59. Kris-Etherton PM, Hecker KD, Bonanome A, Coval SM, Binkoski AE, Hilpert KF, et al. Bioactive compounds in foods: their role in the prevention of cardiovascular disease and cancer. Am J Med. 2002;113(9):71-88.

60. Huang M-T, Ferraro T. Phenolic compounds in food and cancer prevention. ACS Publications; 1992

61. Rice-Evans C, Miller N. Antioxidant activities of flavonoids as bioactive components of food. Biochem Soc Trans. 1996;24(3):790-5.

62. Santos DI, Saraiva JMA, Vicente AA, Moldão-Martins M. Methods for determining bioavailability and bioaccessibility of bioactive compounds and nutrients. Innovative thermal and non-thermal processing, bioaccessibility and bioavailability of nutrients and bioactive compounds: Woodhead Publishing; 2019. p. 23-54. http://hdl.handle.net/1822/61661, https://doi.org/ 10.1016/B978-0-12-814174-8.00002-0.

\section{Publisher's Note}

Springer Nature remains neutral with regard to jurisdictional claims in published maps and institutional affiliations.

Ready to submit your research? Choose BMC and benefit from:

- fast, convenient online submission

- thorough peer review by experienced researchers in your field

- rapid publication on acceptance

- support for research data, including large and complex data types

- gold Open Access which fosters wider collaboration and increased citations

- maximum visibility for your research: over $100 \mathrm{M}$ website views per year

At $B M C$, research is always in progress.

Learn more biomedcentral.com/submissions 